\title{
Perforation Repair Using Biodentine: A Nobel Approach
}

\author{
L. R. Surender, Dinapadu Sainath, C. Rakesh Reddy, T. V. Laxmi Gayathri \\ Department of Conservative and Endodontics, SVS Institute of Dental Sciences, Appanapally, Mahabubnagar, Telangana State \\ E-mail for correspondences: gayathrirao9@gmail.com
}

\begin{abstract}
Root perforations are one of the many consequences of compromised endodontic procedure. It not only poses a significant problem in treatment outcome but also greatly affects the prognosis if not repaired in time. If it occurs, it allows microbial invasion and inflammation in the non-invaded area of operation. Hence, the choice of restorative material should be such that it closes the pathway of communication between the root canal system and its associated tissues. It should possess all the good qualities of an ideal orthograde or retrograde filling material. The following note describes a case report of a young male with failed root canal treatment performed earlier with its steps of management.
\end{abstract}

Key words: Endodontics, inflammation, perforation.

\section{INTRODUCTION}

Endodontic mishaps or procedural accidents are unfortunate occurrences that can occur during treatment. A well-done root canal procedure can be destroyed in a few seconds by a misdirected postspace preparation or during endodontic treatment. Unfortunately, perforations are the common cause of failure when endodontically treated teeth are restored. These failures are mainly due to improper restorative concept and poor clinical judgment. Accidental root perforations do occur in approximately $2-12 \%$ of endodontically treated teeth that might have serious implications. ${ }^{[1-6]}$ Such perforation acts as an open channel encouraging bacterial entry either from root canal or periodontal tissues or both eliciting inflammatory response that results in fistulae. When perforation occurs laterally or in furcation area, there might be overgrowth of gingival epithelium toward the perforation site worsening prognosis of the tooth on its size with appropriate choice of material and technique. ${ }^{[7]}$

\begin{tabular}{|c|c|}
\hline Quick Response Code & Article Info: \\
\hline \multirow{5}{*}{ 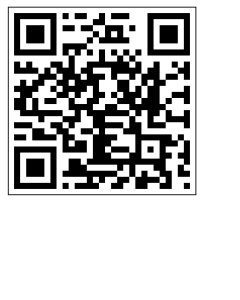 } & doi: $10.5866 / 2018.10 .10112$ \\
\hline & Received: 24-07-2018 \\
\hline & Revised: $28-08-2018$ \\
\hline & Accepted: $10-09-2018$ \\
\hline & $\begin{array}{l}\text { Available Online: } 25-09-2018 \text {, (www. } \\
\text { nacd.in)(C NAD, } 2018 \text { - All rights } \\
\text { reserved }\end{array}$ \\
\hline
\end{tabular}

Biodentineis a new tricalcium silicate(Ca3SiO5)based inorganic restorative commercial cement and advertised as "bioactive dentin substitute" and was introduced by Gilles and Olivier, in 2010. ${ }^{[8]}$ It is composed of tricalcium silicate, dicalcium silicate, calcium carbonate, zirconium oxide, and iron oxide in powder form. The liquid contains calcium chloride and hydrosoluble polymer. ${ }^{[9]}$ It has a setting time of 9-12 min and the highest compressive strength due to the low water/cement ratio compared to the other tested materials. It also has increased resistance to erosion and microleakage than MTA, Dycal, and GIC. It has high alkaline $\mathrm{pH}$ and is an excellent biocompatible material. All such properties make it a favorable material for perforation repair. ${ }^{[9,10]}$

Root perforations have been classified by Fuss and Trope as coronal, crestal, and apical perforation: Coronal perforation - coronal to the level of crestal bone and epithelial attachment with minimal damage to the supporting tissues and easy access, crestal perforation - at the level of the epithelial attachment into the crestal bone, and apical perforation - apical to the crestal bone and the epithelial attachment. Out of these, apical perforation has good prognosis.

\section{CASE REPORT}

A 35-year-old female reported to the Department of Conservative Dentistry and Endodontics of SVS dental college, Mahabubnagar with a chief 


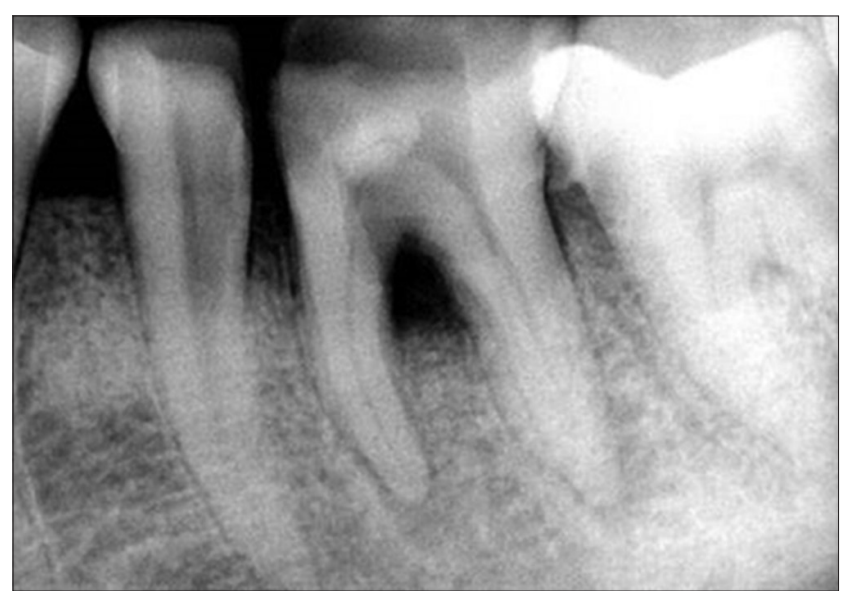

Figure 1: Pre-operative IOPA radiograph shows incomplete endodontic treatment with perforation at the furcation area in relation to 46

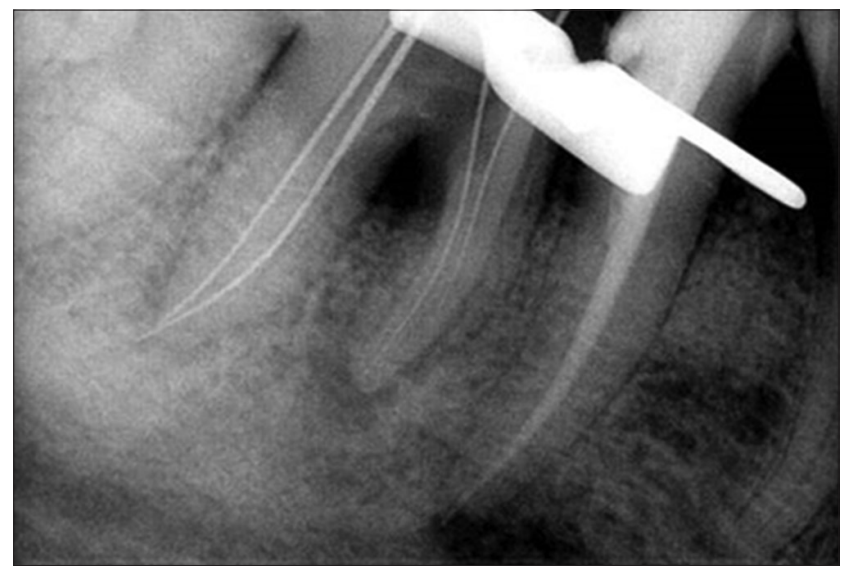

Figure 2: Determination of working length

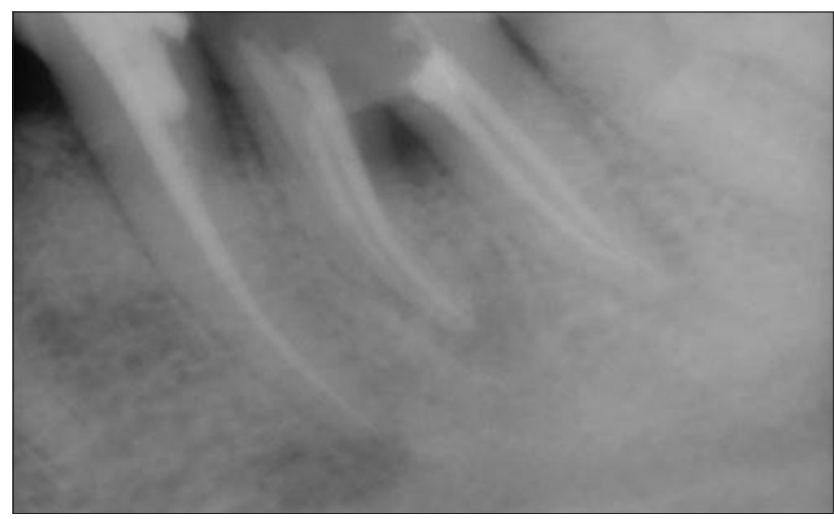

Figure 3: Perforation repair with biodentine

complaint of pain in relation to lower right back region since 6 months. The patient briefed about root canal treatment performed earlier following which pain and occasional pus discharge occurred. Prior

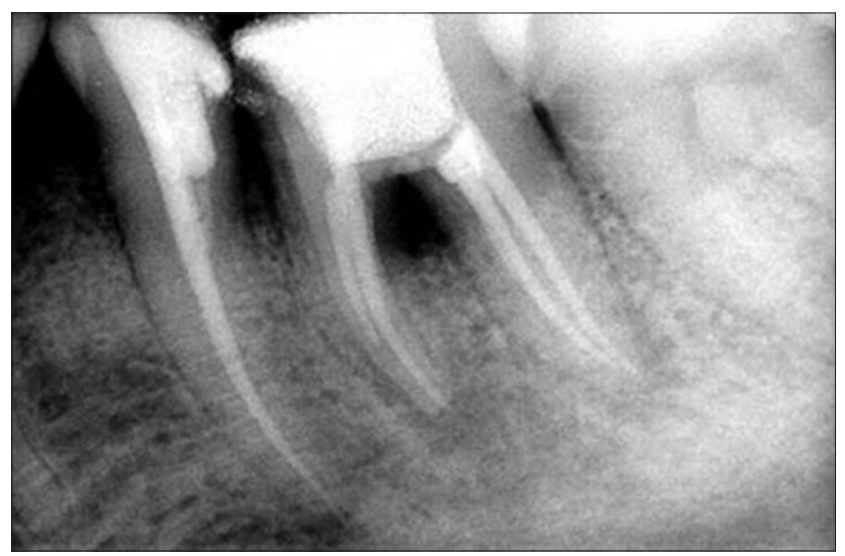

Figure 4: Post-operative IOPA radiograph showing complete obturation of 46

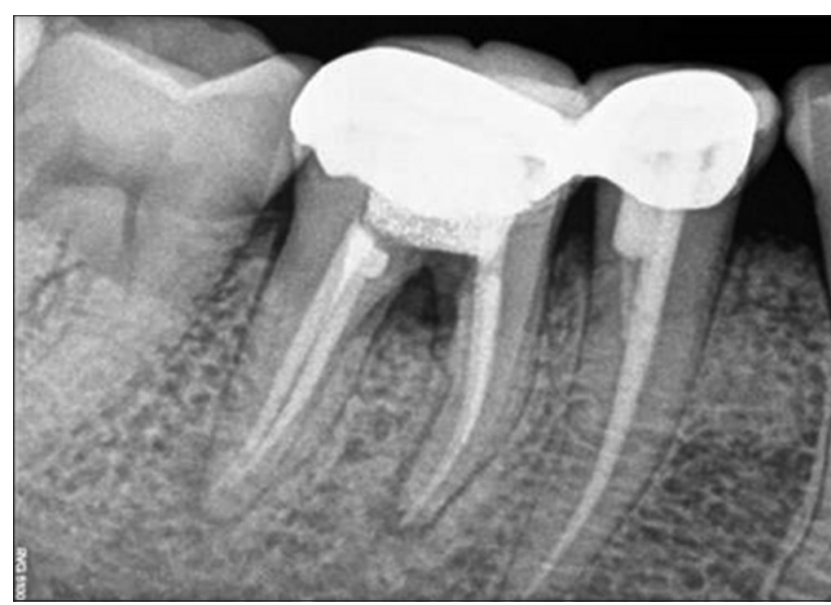

Figure 5: Follow-up IOPA radiograph after 6 months shows no pathology

to reporting to the institution, the patient managed the symptoms with the counter prescription drugs. Intra-oral periapical radiograph revealed incomplete endodontic treatment with perforation at the furcation area [Figure 1]. However, no evidence of periapical pathology was present in relation to the tooth. Based on the clinical findings, retreatment of tooth was advised and the patient agreed. Access was regained and perforation was sealed with biodentine (septdont). Following working length determination, cleaning and shaping with $\mathrm{K}$ type instruments and protaper file system (Dentsply, Maillefer, Tulsa, USA) was done [Figures 2 and 3]. Calcium hydroxide (Endocal, Septodont) was administered as an intracanal medicament. The access preparation was sealed with a cotton pellet and cavit. In the next appointment, master cone IOPA was done and canals were obturated. It was 
followed by placement of post endodontic restoration [Figure 4]. Patient was recalled after few months and was found to be asymptomatic [Figure 5]. So, it can be said that the material "biodentine" showed encouraging results.

\section{DISCUSSION}

Root perforations can occur pathologically as a result of resorption and caries or iatrogenically during root canal treatment. ${ }^{[11]}$ The root perforations can be identified by radiographs, direct observation of bleeding by an apex locator, or a paper point. ${ }^{[12]}$ Perforations are also usually painful. Furcal perforation causes secondary inflammation of the periodontal attachment, which can lead to the loss of tooth if not treated. Treatment should seal the pathways of communication between the root canal system and its surrounding tissues. Filling material so should be biocompatible, non-toxic, noncarcinogenic, easily obtainable, convenient to use, inexpensive, and promote the growth of cementum or allow for its replacement by new, healthy bone by acting as a barrier against which the root canal obturating material can be placed. ${ }^{[13,14]}$ However, prognosis depends on the contamination, size, and location of perforation site. ${ }^{[15,16]}$ In a study by Guneser et al., biodentine showed considerable performance as a perforation repair material even after being exposed to various endodontic irrigants as compared to MTA. ${ }^{[17]}$

\section{CONCLUSION}

With new knowledge, technology and advancements in dentistry, specifically endodontics have vastly improved the quality of care rendered to patients, so we are able to keep many teeth that in the past would have been extracted and possibly replaced with an implant or a fixed or removable partial denture. Hence, thorough idea regarding its restorability is essential which includes knowledge of site, size, time of perforation, and choice of materials selected. Biodentin is a promising restorative material with less cost and better handling properties.

\section{REFERENCES}

1. Kvinnsland I, Oswald RJ, Halse A, Grønningsaeter AG. A clinical and roentgenological study of 55 cases of root perforation. Int Endod J 1989;22:75-84.
2. Ingle JI. A standardized endodontic technique utilizing newly designed instruments and filling materials. Oral Surg Oral Med Oral Pathol 1961;14:83-91.

3. Seltzer S, Bender IB, Smith J, Freedman I, Nazimov H. Endodontic failures an analysis based on clinical, roentgenographic, and histologic findings. II. Oral Surg Oral Med Oral Pathol 1967;23:517-30

4. Kerekes K, Tronstad L. Long-term results of endodontic treatment performed with a standardized technique. J Endod 1979;5:83-90.

5. Sinai IH, Romea DJ, Glassman G, Morse DR, Fantasia J, Furst ML, et al. An evaluation of tricalcium phosphate as a treatment for endodontic perforations. J Endod 1989;15:399-403.

6. Farzaneh M, Abitbol S, Friedman S. Treatment outcome in endodontics: The Toronto study. Phases I and II: Orthograde retreatment. J Endod 2004; 30:627-33.

7. Tsesis I, Fuss Z. Diagnosis and treatment of accidental root perforations. Endod Top 2006;13:95-107.

8. Gilles R, Olivier M. Dental Composition. Patent 2011, WO 2011/124841, US 2013/0025498. Saint-Maurdes Fosses, France: Applicant Septodont.

9. Han L, Okiji T. Uptake of calcium and silicon released from calcium silicate-based endodontic materials into root canal dentine. Int Endod J 2011;44:1081-7.

10. Priyalakshmi S, Ranjan M. Review of biodentine a bioactive dentin substitute. IOSR J Dent Med Sci 2014;13:13-7.

11. Nicholls E. Treatment of traumatic perforations of the pulp cavity. Oral Surg Oral Med Oral Pathol 1962;15:603-12.

12. Alhadainy HA, Himel VT. Evaluation of the sealing ability of amalgam, cavit, and glass ionomer cement in the repair of furcation perforations. Oral Surg Oral Med Oral Pathol 1993;75:362-6.

13. Jew RC, Weine FS, Keene JJ Jr. Smulson MH. A histologic evaluation of periodontal tissues adjacent to root perforations filled with cavit. Oral Surg Oral Med Oral Pathol 1982;54:124-35.

14. ElDeeb ME, ElDeeb M, Tabibi A, Jensen JR. An evaluation of the use of amalgam, cavit, and calcium hydroxide in the repair of furcation perforations. J Endod 1982;8:459-66.

15. Oswald RJ. Procedural accidents and their repair. Dent Clin North Am 1979;23:593-616.

16. Balla R, LoMonaco CJ, Skribner J, Lin LM. Histological study of furcation perforations treated with tricalcium phosphate, hydroxylapatite, amalgam, and life. J Endod 1991;17:234-8

17. Guneser MB, Akbulut MB, Eldeniz AU. Effect of various endodontic irrigants on the push-out bond strength of biodentine and conventional root perforation repair materials. J Endod 2013;39:380-4. 